\title{
Lipid composition of the pacific lion-paw scallop, Nodipecten subnodosus, in relation to gametogenesis
}

\section{Lipid classes and sterols}

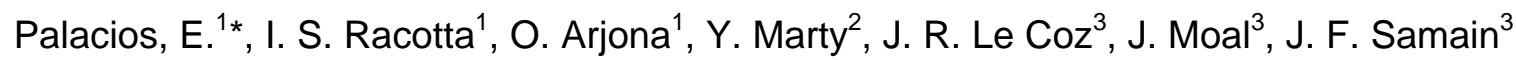 \\ ${ }^{1}$ CIBNOR, A.P. 128, La Paz, B.C.S. 23000, México \\ 2 UMR CNRS 6521, Université de Bretagne Occidentale, CS 93837, 29238 Brest Cedex 3, France \\ 3 IFREMER, Laboratoire de physiologie des mollusques (UMR 100 - Physiologie et Ecophysiologie des \\ Mollusques Marins), BP 70, 29280 Plouzané, France \\ ${ }^{*}$ Corresponding author: Elena Palacios \\ Centro de Investigaciones Biológicas del Noroeste, Mar Bermejo 195, Col. Playa Palo de Santa Rita, A.P. 128, La \\ Paz, B.C.S., 23000, México. \\ e-mail: epalacio@cibnor.mx \\ tel: +52 (612) 1238508 \\ fax: $+52(612) 1253625$
}

\begin{abstract}
:
Knowledge on the energy distribution during the reproductive cycle of the giant lion-paw scallop, Nodipecten subnodosus is limited, but necessary for aquaculture purposes. In a previous work, we found that natural food availability can sustain the full cost of gametogenesis in optimal environmental conditions. The present study analyses the lipid and sterol classes' composition of several tissues during gametogenesis. In female gonads, the quantity of triacylglycerol (TG) increased parallel to gametogenesis from December (spawned gonads, $0.7 \mathrm{mg} \mathrm{g}^{-1}$ or $7 \%$ of total lipids) to June (ripe gonads, $52 \mathrm{mg} \mathrm{g}^{-1}$ or $66 \%$ of total lipids). In male gonads sampled in June, the concentration of TG (0.7 $\mathrm{mg} \mathrm{g}^{-1}$ or $3.5 \%$ of total lipids) and esterified sterols was significantly lower than in female gonads. Total phospholipids (PL) increased two-fold in female gonads of scallops sampled in June compared to the other months, which could be a result of oocyte production and growth, but no differences were found in the concentration of PL or in free sterol composition between male and female gonads. TG concentration in the digestive gland was similar in December and February $\left(37-38 \mathrm{mg} \mathrm{g}^{-1}\right.$ or $68 \%$ of total lipids), but increased eight-fold by April and remained high in June $\left(252-277 \mathrm{mg} \mathrm{g}^{-1}\right.$ or $90 \%$ of total lipids). Together with the increase in esterified sterols, these data suggest an increase in food availability during these months. A lack of decrease of TG levels in digestive gland during gonad development is in accordance to sufficient food availability in this location to satisfy the energetic demands of gametogenesis. Cholesterol was the principal sterol found in all tissues; its concentration, as well as the concentration of several phytosterols, remained constant throughout the maturation process, except in digestive gland where they increased from December to June, further supporting an increased availability of food. However, the presence of several phytosterols in substantial concentrations, mainly brassicasterol and 24-methylenecholesterol in gonad and somatic tissues, further supports a specific physiological role of these sterols in pectinids.
\end{abstract}

Keywords: Acylglycerides; Mollusks; Phospholipid; Reproduction; Sterol 


\section{Introduction}

The giant lion-paw scallop (Nodipecten subnodosus) represents an important fishery resource along the Baja California Pacific Coast in Mexico, and several promising attempts have been made to implement its culture (Félix-Pico et al., 1999; Barrios-Ruiz et al., 2003; Racotta et al., 2003). Recent works have analyzed the energy distribution during the reproductive cycle of the giant lion-paw scallop (Racotta et al., 2003; Arellano-Martínez et al., 2004). It has been well documented that during gametogenesis of most pectinids, lipids are transferred to the gonads from other tissues for yolk synthesis (Barber and Blake, 1981; Martinez, 1991; Pazos et al., 1997; Lodeiros et al., 2001). Transfer of lipids from digestive gland to gonads was observed in wild $\mathrm{N}$. subnodosus collected from Guerrero Negro (BCS, Mexico), a medium productive site (Arellano-Martinez et al., 2004). However, Racotta et al. (2003) found, in an 18-month study of $\mathrm{N}$. subnodosus that there was no important pattern of energy mobilization from muscle and digestive gland to gonads during reproduction. This study concerned a population of lion-paw scallop introduced for aquaculture purposes to a rich productive southern site (Magdalena Bay, BCS, Mexico) within its geographical limits. They concluded that the natural food availability at this site could sustain both the full cost of gametogenesis and their somatic growth, similarly to results described for other pectinids (Pazos et al., 1997; Luna-González et al., 2000; Roman et al., 2001). A study involving a more detailed lipid analysis of several types of tissues of the lion-paw scallops sampled over a six-month period including gametogenesis has been performed. The fatty acid composition data obtained from this study has been published (Palacios et al., 2005), and revealed a minimal transfer of fatty acids from other tissues to gonads during gametogenesis. The present paper reports the changes of lipid class and sterol composition of this study.

\section{Materials and Methods}

Growth and sampling of scallops was done as described by Racotta et al. (2003). Briefly,

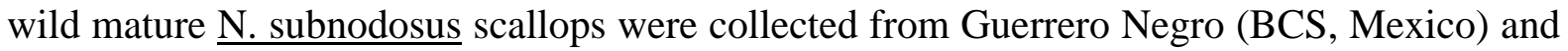
induced to mass spawn by alternating cold and hot water shocks (October 1999). At spat stage, the scallops were transported to the growout area in Magdalena Bay (BCS, Mexico) and grown in Nestier trays at a density of 110 scallops per tray. For lipid analyses, five scallops were collected bimonthly from December 1999 until June 2000 and transferred to the laboratory at Centro de Investigaciones Biológicas del Noroeste (CIBNOR, La Paz, BCS, Mexico). Upon arrival, general morphometric traits and tissue weight were recorded, and samples of mantle, digestive gland, adductor muscle, and gonads were stored at $-80^{\circ} \mathrm{C}$ for individual lipid analyses. Only in June 2000, were sufficient male gonadal tissues obtained for lipid analysis.

Lipids were extracted with chloroform:methanol (2:1) according to Bligh and Dyer (1959) and the lipid extract was stored at $-20^{\circ} \mathrm{C}$ in chloroform under a nitrogen atmosphere until further analysis. Total lipid samples were run on thin layer chromatography coupled to detection by flame ionization (Iatroscan TLC/FID MK-5 analyzer), using chromarods S-III, which were previously brought to a constant humidity in a hydration chamber (Ackman and Heras, 1997; Palacios et al., 2001). Neutral lipid classes were developed for $35 \mathrm{~min}$ in a mobile phase of hexane: ethyl acetate: diethyl ether: formic acid (90:7:3:1). Rods were scanned at a hydrogen flow rate of $160 \mathrm{~mL} / \mathrm{min}$, airflow of $2000-\mathrm{mL} / \mathrm{min}$, and a scanning speed of 30-mm/min. Lipid classes were identified by comparison of retention times against appropriate external standards (Sigma, St. Louis, USA), and concentration was calculated based on the peak areas of these external standards. 
Lipid extracts were also transported to Université de Bretagne Occidentale (UBO, Brest, France) and neutral and polar lipid fractions were separated in a silica-gel microcolumn and collected in vials containing $0.01 \%$ butylated hydroxytoluene (BHT) as antioxidant (Marty et al., 1992). Free and esterified sterols from the neutral lipid fraction were separated at Institut Français de Recherche pour L'exploitation de la Mer (IFREMER, Brest, France) by High Performance Liquid Chromatography (Merck-Hitachi L6200), equipped with an UV detector and a Gilson 203 fractions collector (Soudant et al., 1998). A known quantity of cholestane was added to the free and esterified fractions of sterols as an internal standard $(2.3 \mathrm{mg} / \mathrm{ml})$. The esterified sterols were transesterified with sodium methoxide for $90 \mathrm{~min}$ at ambient temperature, and the released sterols were extracted in hexane. The free sterols were evaporated to dryness and dissolved in hexane. The sterols were analyzed in a Chrompak 9001 gas chromatograph equipped with a CP8 capillary column $(50 \mathrm{~m} \times 0.32 \mathrm{~mm}, 0.2 \mu \mathrm{m}$ film thickness) using an on-column injection system and hydrogen as a carrier gas, with a thermal gradient from 200 to $290^{\circ} \mathrm{C}$ at $5^{\circ} \mathrm{C} / \mathrm{min}$, and a FID detector at $300^{\circ} \mathrm{C}$. The sterols were identified by comparison of their retention time with standards (SUPELCO, Lyon, France).

One-way analyses of variance followed by Tukey test for unequal $N$ post-hoc mean comparisons (Statistica Version 5.0) were used to assess significant differences between months of sampling. The level of significance was set at $P<0.05$. The comparison between the male gonad and the female gonad sampled in June was done with a ' $t$ ' test $(P<0.05)$.

\section{Results}

In gonads, the concentration of triacylglycerol (TG) increased steeply from very low levels in December to maximum values in June (Table 1). Free fatty acid (FFA) concentration had an irregular trend, with higher values in February and June. The concentration of free sterols (FS) and esterified sterols (ES) remained constant throughout the maturation process. The concentration of total phospholipids (PL) increased two-fold by June compared to previous months. The male gonad tissue, which was sampled only in June, had significantly lower concentrations of TG and ES compared to the female gonad sampled in June, although the concentration of TG was the same as the concentration in immature female gonads sampled in December.

The TG concentration in the digestive gland was similar in December and February, but increased seven-fold by April and remained high in June. There was no significant difference in concentration in other lipid classes among sampling months. Contrary to the above tissues, the concentration of TG in muscle was very low and decreased further with advancing maturation, whereas the concentrations of other lipid classes were constant through the sampling period. In mantle, only PL concentrations showed significant differences, increasing throughout the maturation period.

Figure 1 shows the concentration of free and esterified sterols in the four tissues during the period analyzed. In all tissues cholesterol was the major sterol, ranging from 35 to $47 \%$ of total sterols. Others two major sterols were brassicasterol, with levels relatively constant over time regardless of tissue types (15 to $18 \%$ of total sterols), and 24-methylencholesterol which was highly variable from 9\% (digestive gland in December) to 28\% (male gonad in June). Sterols that amounted from 1 to $10 \%$ of total sterols were T-dehydrocholesterol ( 7 to $10 \%$ ), $\beta$-sitosterol (6 to $7 \%$ ), campesterol (4 to $9 \%$, although no campesterol was detected in male gonad and an extreme value of $12 \%$ was present in muscle in February), stigmasterol (1 to $7 \%$, although no stigmasterol was detected in male gonad and in the most mantle samples) and norcholesterol (1 to 4\%). Finally desmosterol was highly variable and ranged from nondetectable to $6 \%$. The same distribution patterns between free and esterified fractions were 
observed for all the sterols. Sterols were mostly found in the free form, except in digestive gland. In the digestive gland, the esterified form of cholesterol increased from $33 \%$ in December to $75 \%$ of total cholesterol in June. Similarly, concentrations of esterified brassicasterol, 24-methylencholesterol and norcholesterol in the digestive gland significantly increased during the sampling period with the highest values in April and June. The exception was stigmasterol, which was found only as a free form, even in the digestive gland. In other organs, including muscle, mantle, and female (and male) gonad, the esterified form represented 0 to a maximum of $15 \%$ of total cholesterol with the highest values in female gonad and, to a lower extent, in muscle. However the concentration of free sterols fraction remained constant in the digestive gland and in other tissues during all the sampling period, except for cholesterol which showed a non-significant decrease of free cholesterol concentration accompanying the increase of esterified cholesterol in the digestive gland. The male gonad had higher concentrations of free brassicasterol, 24-methylencholesterol, norcholesterol, $\beta$-sitosterol and desmosterol than female gonad in June.

\section{Discussion}

In the giant lion-paw scallop, lipid accumulation in gonads has been described in terms of total lipids, total acylglycerides, and fatty acids during gametogenesis (Racotta et al., 2003; Arellano-Martinez et al., 2004; Palacios et al., 2005). The scallops used in the present study were the same as those in previous studies (Racotta et al., 2003; Palacios et al., 2005), where the date and state of gonad development was reported. Briefly, scallops sampled in December of 1999 were one year old and at the end of their first maturation. After reproductive quiescence in January 2000, an increase in gametogenesis activity was observed in February (second sampling) and then a peak in sexual maturity was observed in April (third sampling), when histological analyses showed that some scallops had already spawned. When the last samples were taken for lipid analyses in June, scallops were mature again. In the present study, TG measured by TLC-FID, showed a similar pattern to acylglycerides measured by microenzymatic test (Racotta et al., 2003) and the fatty acids in neutral lipids (Palacios et al., 2005), increasing in female gonads from December to June. The first increase in TG concentration from February to April, and a further increase from April to June, is in accordance with an initial maturation and facultative spawning in April, while the main reproductive peak started in June, as previously discussed by Palacios et al. (2005).

We did not find decreasing levels of TG in the digestive gland concomitant with gonad development, as would be expected if TG is transferred from this tissue to gonad (Villalaz, 1994). Moreover, TG was the predominant lipid class in the digestive gland and its highest levels were observed in April and June, concomitantly with gonad development. In contrast, Arellano-Martinez et al. (2004) found a transference of acylglycerides from digestive gland to gonad in wild lion-paw scallops sampled at a medium productive site in the north, Ojo de Liebre Lake, Guerrero Negro (BCS, Mexico). This could be explained by differences in food availability in the two localities: in Magdalena Bay (present study), Chlorophyll-a concentrations can vary from 0.4 to $4.5 \mathrm{mg} / \mathrm{m}^{3}$ (Martínez-López and Verdugo-Díaz, 2000), while in Ojo de Liebre Lake these are between 0.1 to $1.5 \mathrm{mg} / \mathrm{m}^{3}$ (Hernández-Rivas et al., 2000; Arellano-Martinez et al., 2004). The differences in TG storage in scallops can be attributed to the difference in food availability of the two sites, because scallops grown in Magdalena Bay were the offspring of scallops previously sampled at Guerrero Negro, so both populations were similar genetically. These results confirms that natural food availability could sustain the full cost of gametogenesis in this species in optimal environmental conditions as previously suggested for this species (Racotta et al., 2003; Palacios et al., 2005) and other pectinids (Pazos et al., 1997; Luna-González et al., 2000; Roman et al., 2001). The 
concentration of TG in digestive gland was always higher in comparison to TG concentration in gonads, even during full maturity in June, which supports the role of the digestive gland as lipid or TG reservoir (Napolitano and Ackman, 1992; Saout et al., 1999; Caers et al., 2003). Lipids in the digestive gland increase during phytoplankton blooms (Starr et al., 1990; Napolitano and Ackman, 1992; Paulet et al., 1997; Duinker et al., 2004) or when algae are particularly rich in lipids (Navarro et al., 2000). In the present study, in addition to the pronounced increase in TG, several esterified sterols (see below) and fatty acids in the neutral fraction (Palacios et al., 2005) also increased in April and June in digestive gland. This further suggests that there was sufficient food to support the full cost of gametogenesis at that time period. Although chlorophyll- $a$ levels were not measured in this study, maximum concentrations are reported for May for the same location (Rosales-Villa, 2004).

In relation to other tissues that store reserves to be further used for gonad development, we found that carbohydrates and proteins from adductor muscle were not mobilized for gametogenesis in giant lion-paw scallops grown in the same location (Racotta et al., 2003). However, there was a decrease in TG concentration in muscle starting in February, which could indicate its transfer to gonad. However, given the high TG levels in digestive gland in comparison to muscle, TG transfer from the later to gonad is small. A lack of mobilization of reserves from muscle could be the reason giant lion-paw scallop triploids grown at Magdalena Bay do not have a bigger adductor muscle or higher total tissue weight compared to diploids (Maldonado-Amparo et al., 2004). Mantle, similarly to muscle, seems to mobilize minimal reserves during maturation, in agreement with Martinez (1991) who suggested that the mantle of Argopecten purpuratus is a site of storage of metabolic substrate to be utilized for growth rather than gametogenesis. PL in mantle increased by April and June, which could be a result of growth in this somatic tissue, occurring concomitantly to reproduction.

The comparison of the male and female gonad tissues is interesting, because lipids in the male gonad are used principally as components of cellular membranes of sperm, which composes the major part of the male gonad, and might have a particular lipid composition due to its function and high motility. On the other hand, lipids in the female gonad are used both as components of cellular membranes, and as energy reserves accumulated in oocytes (Soudant et al., 1997; Pernet et al., 2003). In the female gonad, the TG was the predominant lipid in mature scallops, compared to immature scallops and to mature male gonads. Also the PL concentration increased in female gonads in June and finally had a slightly higher concentration of PL than males, which is in accordance to a role of some PL classes, such as phosphatidylcholine, as energy reserves (Soudant et al., 1996b). Gabbot (1975) also concluded that high PL content of the eggs contributed to the energy metabolism of the early larvae.

A similar and constant levels of free sterols found in the different tissues were in accordance to their role in cellular membranes. Cholesterol was the major sterol, in free and esterified form, underlying the specific importance of that sterol in cell metabolism. Nevertheless, the presence of phytosterols in all tissues implies that these sterols could substitute for cholesterol in the cellular membrane. The distribution of major sterols among the four tissues was similar to the results reported in Placopecten by Napolitano et al. (1993), who proposed that sterols are incorporated in a non-specific form into tissues. However, this incorporation varies with the time of the year (present study) or changes in food supply and during somatic growth (Napolitano et al., 1993, Soudant et al., 1996a, Roman et al., 1997). In addition, sterol composition changes in muscle and mantle during somatic growth (Napolitano and Ackman, 1992), because sterols are important membrane components. However we did not observe significant changes in sterol composition during our sampling periods. 
Bivalve mollusks have a limited capacity for cholesterol synthesis or bioconversion of phytosterols into cholesterol (Teshima, 1982; Napolitano et al., 1993; Kanazawa, 2001). As a consequence, the phytosterols present in pectinids reflect the ingested microalgae (Idler and Wiseman, 1972). Different algae classes synthesize specific phytosterols (Marlowe et al., 1984). Although we did not analyze the phytoplankton composition where the giant lion-paw scallops were grown, the sterol composition in several tissues, particularly in the digestive gland, can be used as biomarkers of ingested microalgae (Napolitano et al., 1993; Soudant et al., 1996a; 1998). For example, brassicasterol, has been reported in high concentrations (90\%) in Isochrysis sp. (Berenberg and Patterson, 1981; Volkman et al., 1981; Marlowe et al., 1984; Napolitano et al., 1993; Soudant et al., 1998, Muller-Feuga et al., 2003), and 24methylenecholesterol, and also cholesterol could come from diatomophyceae such as Chaetoceros or Skeletonema (Napolitano et al., 1992; Tsitsa-Tzardis et al., 1993; Soudant et al., 1998). The increase in esterified sterols in the digestive gland in April and June could therefore indicate increased availability of these microalgae in Magdalena Bay during these months. Such accumulation of sterols in the digestive gland as reserves is consistent with the accumulation of TG, in this organ, at the same time. The accumulated TG and sterols could be energy reserves and fatty acids reservoir. Cholesterol was the major sterol found in the digestive gland, indicating that this sterol was preferentially incorporated as previously pointed out (Berenberg and Paterson, 1981; Soudant et al., 1996a), due to the essentiality of this sterol. A non-negligible part of steryl esters were also found in the female gonad. This confirms that they were stored in oocytes as reserves (Soudant et al., 1996a). However, while the female gonads had some esterified phytosterols, the male gonad had only esterified cholesterol. Moreover, in muscle only cholesterol was found as an esterified form in several samplings, indicating the importance of this form as a cholesterol reservoir.

\section{Conclusions}

Little or no transfer of lipid classes from other tissues to gonads occurs during gametogenesis of $\underline{N}$. subnodosus at the culture site at Magdalena Bay. Increased levels of TG and esterified sterols in the digestive gland concomitant to gonad development indicate sufficient food supply to sustain the lipids needs for gametogenesis at this site. Differences in lipid composition between male and female portions of gonad are related to specific role of different lipids for oocyte and sperm development.

\section{Acknowledgments}

We are grateful to Ing. Ac. Jose Luis Ramírez for his help during sampling, to Ira Fogel for editing the English-language text, and to an anonymous reviewer for his/her comments. This research was supported by SIMAC project BCS7001. 


\section{References}

Ackman, R.G., Heras, H. 1997. Recent applications of Iatroscan TLC-FID methodology. In: R. E. McDonald and M. M. Mossoba (Eds.) New Technology and applications in lipid analysis. pp. 325-340. AOCS Press, Champaign, Illinois.

Arellano-Martinez, M., Racotta, I.S., Ceballos-Vázquez, B.P., Elorduy-Garay, J.F. 2004. Biochemical composition, reproductive activity, and food availability of the lion's paw scallop Nodipecten subnodosus in the laguna Ojo de Liebre. Baja California Sur, Mexico. J. Shellfish Res. 23, 15-23.

Barber, B.J., Blake, N.J. 1981. Energy storage and utilization in relation to gametogenesis in Argopecten irradians concentricus (Say). J. Exp. Mar. Biol. Ecol. 52:121-134.

Barrios-Ruiz, D., Chávez-Villalba, J., Cáceres-Martinez, C. 2003. Growth of Nodipecten subnodosus (Bivalvia: Pectinidae) in La Paz Bay, Mexico. Aquacult. Res. 34, 633-639.

Berenberg, C., Patterson, G. W. 1981. The relationship between dietary phytosterols and the sterols of wild and cultivated scallops. Lipids 16:276-278.

Bligh, E. G., W. J. Dyer. 1959. A rapid method of total lipid extraction and purification. Can. J. Biochem. Physiol. 37, 911-917.

Caers, M., Coutteau, P., Sorgeloos, P., Gajardo, G. 2003. Impact of algal diets and emulsions on the fatty acid composition and content of selected tissues of adult broodstock of the Chilean scallop Argopecten purpuratus (Lamarck, 1819). Aquaculture 217:437-452.

Duinker, A., Torstensen, B.E., Lie, Ø. 2004. Lipid classes and fatty acid composition in female gonads of great scallops - a selective field study. J. Shellfish Res., 23: 507-514.

Félix-Pico, E.F., Villalejo-Fuerte, M., Tripp-Quezada, A., Holguin-Quiñones, O. 1999. Growth and survival of Lyropecten subnodosus (Sowerby, 1835) in suspended culture at the national marine park of Bahia de Loreto, B.C.S., Mexico. 12th Inter. Pectinid Workshop., Bergen, Norway. pp. 39-40.

Gabbot, P. A. 1975. Storage cycles in marine bivalve molluscs: a hypothesis concerning the relationship between glycogen metabolism and gametogenesis. Barnes, H. (Ed.) Proc.9th Europ. Mar. Biol. Symp., Aberdeen University Press, pp. 191-211.

Hernández-Rivas, M.E., Jiménez-Rosenberg, S.P., Funes-Rodríguez, R., Saldierna-Martínez, R.J. 2000. El centro de actividad biológica de la Bahía de Sebastián Vizcaíno, una primera aproximación. In: Lluch-Belda, D., Elorduy-Garay, J., Luch-Cota, S.E., Ponce-Díaz, G. (Eds.), Centros de Actividad Biológica del Pacífico Mexicano. CIBNOR-CONACYT, La Paz, BCS, Mexico, pp. 65-85.

Idler, D.R., Wiseman, P. 1972. Molluscan sterols: A review. J. Fish. Res. Bd. Canada 29, 385-398.

Kanazawa, A. 2001. Sterols in marine invertebrates. Fisheries Sc. 67, 997-1007

Lodeiros, C.J., Rengel, J.J., Guderley, H., Nusetti, O.A., Himmelman, J.H. 2001. Biochemical composition and energy allocation in the tropical scallop Lyropecten (Nodipecten) nodosus during the months leading up to and following the development of gonads. Aquaculture 199, 63-72.

Luna-Gonalez, A., Caceres, C., Zuñiga-Pacheco, C, Lopez-Lopez, S., Ceballos-Vázquez, B.P. 2000. Reproductive cycle of Argopecten ventricosus (Sowerby 1842) (Bivalvia: Pectinidae) in the rada del Puerto de Pichilingue, B.C.S., and its relation to temperature, salinity and food. J. Shellfish Res. 19, 107-112.

Maldonado-Amparo, R., Ramírez, J.L., Avila, S., Ibarra, A.M. 2004. Triploid lion-paw scallop (Nodipecten subnodosus Sowerby); growth, gametogenesis, and gametic cell frequencies when grown at a high food availability site. Aquaculture 235, 185-205.

Marlowe, I.T., Green, J.C., Neal, A.C., Brassel, S.C., Eglinton, G., Course, P.A. 1984. Longchain (n-C37-C39) alkelones in the Prymnesiophyceae. Distribution of alkenones and 
other lipids and their taxonomic significance. Br. Phycol. J. 19, 203-216.

Martinez, G. 1991. Seasonal variations in biochemical composition of three size classes of the Chilean scallop Argopecten purpuratus Lamarck, 1819. The Veliger 34, 335-343.

Martínez-López, A., Verdugo-Díaz, G. 2000. Composición y dinámica del fitoplancton en el BAC de Bahía Magdalena, B.C.S. In: Lluch-Belda, D., Elorduy-Garay, J., Luch-Cota, S.E., Ponce-Díaz, G. (Eds.), Centros de Actividad Biológica del Pacífico Mexicano. CIBNOR/CONACYT, La Paz, BCS, Mexico, pp. 125-142.

Marty, Y., Delaunay, F., Moal, J., Samain, J.F. 1992. Changes in the fatty acid composition of Pecten maximus (L.) during larval development. J. Exp. Mar. Biol. Ecol. 163, 221-234.

Muller-Feuga, A., Moal , J., Kaas, R. 2003. The microalgae of aquaculture. In: Stottrup J.G. and McEvoy L.E. (Eds), Live feeds in marine aquaculture. Blackwell Science Ltd, UK, pp. 221-232

Napolitano, G. E., Ackman, R.G. 1992. Anatomical distributions and temporal variations of lipid classes in sea scallop Placopecten magellanicus (Gmelin) from Georges Bank (NovaScotia). Comp. Biochem. Physiol. 103B, 645-650.

Napolitano, G.E., MacDonald, B.A., Thompson, R.J., Ackman, R.G. 1992. Lipid composition of eggs and adductor muscle in giant scallops (Placopecten magellanicus) from different habitats. Mar. Biol. 113, 71-76.

Napolitano, G.E., Ackman, R.G., Silva-Serra, M.A. 1993. Incorporation of dietary sterols by the sea scallop Placopecten magellanicus fed on microalgue. Mar. Biol. 117, 647-654.

Navarro, J.C., Leyva, J.E., Martinez, G., Aguilera, C. 2000. Interactive effects of diet and temperature on the scope for growth of the scallop Argopecten purpuratus during reproductive conditioning. J. Exp. Mar. Biol. Ecol. 247, 67-86.

Palacios, E., Racotta, I.S., Kraffe, E., Marty, Y., Moal, J., Samain, J.F. 2005. Lipid composition of the Pacific lion-paw scallop, Nodipecten (Lyropecten) subnodosus, in relation to gametogenesis. I. Fatty acids. Aquaculture, 250, 270-282.

Palacios, E., Racotta, I.S., Heras, H., Marty, Y., Moal, J., Samain, J.F. 2001. Relation between lipid and fatty acid composition of eggs and larval survival in white pacific shrimp (Penaeus vannamei, Boone, 1931). Aquacult. Int. 9, 531-543.

Paulet, Y.M., Bekhadra, F., Donval, A., Saout, C. 1997. Constancy and variation in the reproductive cycle of Pecten maximus in the Bay of Brest, France: an eight year study. Félix-Pico, E. (Ed.) pp. 98-99. La Paz, México, 11th Inter. Pectinid Workshop.

Pazos, A.J., Roman, G., Acosta, C.P., Abad, M., Sanchez, J.L. 1997. Seasonal changes in condition and biochemical composition of the scallop Pecten maximus L. from suspended culture in the Ria de Arousa (Galicia, N.W. Spain) in relation to environmental conditions. J. Exp. Mar. Biol. Ecol. 211, 169-193.

Pernet, F., Tremblay, R., Demers, E. Bourget, E. 2003. Biochemical indicator of sea scallop (Placopecten magellanicus) quality based on lipid class composition. Part I: Broodstock conditioning and young larval performance. J. Shellfish Res. 22, 365-375.

Racotta, I.S., Ramirez, J.L. Ibarra, A.M., Rodriguez-Jaramillo, M.C., Carreño, D., Palacios, E. 2003. Growth and gametogenesis in the lion-paw scallop Nodipecten (Lyropecten) subnodosus. Aquaculture 217, 335-349.

Roman, G., Acosta, C.P., Cano, J., Campos, M.J., Lowe, E. 1997. Reproductive and reserve storage cycles in Aequipecten opercularis. In: Félix-Pico, E. (Ed.), 11th Inter. Pectinid Workshop, La Paz, México. pp. 174-175.

Roman, G., Martinez, G., Garcia, O., Freites, L. 2001. Reproducción. In: Maeda-Martinez, A.N. (Ed.) Los moluscos pectinidos de Iberoamerica: Ciencia y Acuicultura. pp. 27-59. Noriega editores, Mexico.

Rosales-Villa, A.R. 2004. Dinámica de nutrientes en Bahía Magdalena, B.C.S., México. 
Centro Interdisciplinario de Ciencias Marinas, I.P.N. Master Thesis. 104 pp.

Saout, C., Quere, C., Donval, A., Paulet, Y.M., Samain, J.F. 1999. An experimental study of the combined effects of temperature and photoperiod on reproductive physiology of Pecten maximus from the Bay of Brest (France). Aquaculture 172, 301-314.

Sokal, R.R., Rohlf, F.J. 1981. Biometry: The principles and practice of statistics in biological research. W.H. Freeman and Co., New York, second edition, 859 p.

Soudant, P., Marty, Y., Moal, J., Robert, R., Quéré, C., Le Coz, J.R., Samain, J.F. 1996a. Effect of food fatty acid and sterol quality on Pecten maximus gonad composition and reproduction process. Aquaculture 143, 361-378.

Soudant, P., Moal, J., Marty, Y., Samain, J.F. 1996b. Impact of the quality of dietary fatty acids on metabolism and the composition of polar lipid classes in female gonads of Pecten maximus (L.). J. Exp. Mar. Biol. Ecol. 205, 149-163.

Soudant, P., Moal, J., Marty, Y., Samain, J.F. 1997. Composition of polar lipid classes in male gonads of Pecten maximus (L.). Effect of nutrition. J. Exp. Mar. Biol. Ecol. 215, 103-114.

Soudant, P., Le Coz, J.R., Marty, Y., Moal, J., Robert, R., Samain, J.F. 1998. Incorporation of microalgae sterols by scallop Pecten maximus (L.) larvae. Comp. Biochem. Physiol. 119A, 451-457.

Starr, M., Himmelman, J., Therriault, J.C. 1990. Direct coupling of marine invertebrate spawning with phytoplankton blooms. Science 247, 1071-1074.

Teshima, S.I. 1982. Sterol metabolism. In: Pruder, G.D., Lang, G.A., Conklin, D.E. (Eds.), Proceedings of the Second International Conference on Aquaculture Nutrition: Biochemical and Physiological Approaches to Shellfish Nutrition, Special Publication No. 2, 205-215. Baton Rouge, Louisiana, Louisiana State University.

Tsitsa-Tzardis, E., Patternson, G.W., Wikfors, G.H., Gladu, P.K., Harrison, D. 1993. Sterols of Chaetoceros and Skeletonema. Lipids 28, 465-467.

Villalaz, J.R. 1994. Laboratory study of food concentration and temperature effect on the reproductive cycle of Argopecten ventricosus. J. Shellfish Res. 13, 513-519.

Volkman, J.K., Smith, D.J., Eglinton, G.E., Forsberg, T.E.V., Corner, D.S. 1981. Sterol and fatty acid composition of four marine haptophycean algae. J. Mar. Biol. Ass. U. K. 61, 509-527. 

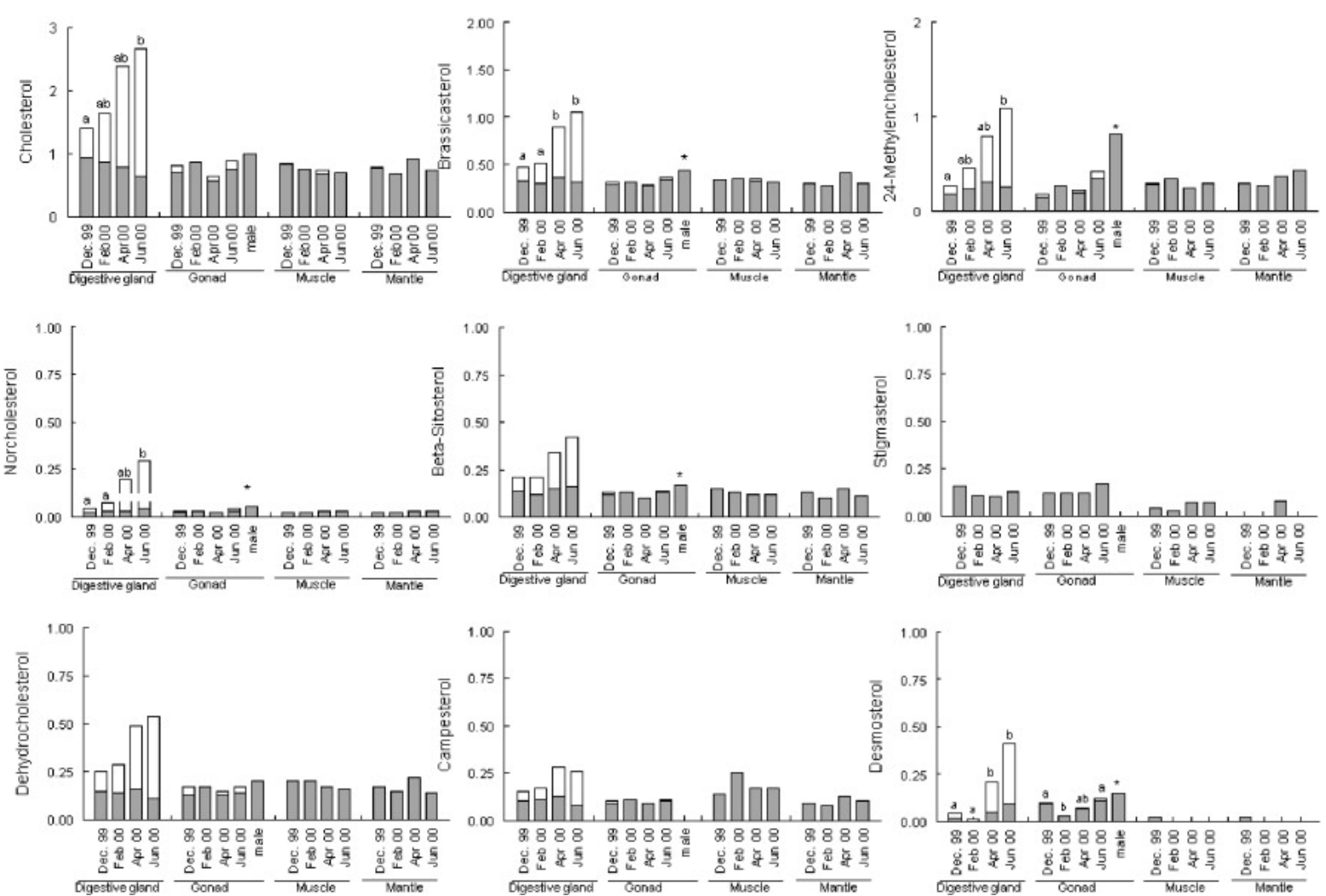

Fig. 1. Sterol concentration (mg/g wet tissue) analyzed by CG-FID in the free (dark bars) and esterified (light bars) fraction separated by HPLC in tissues of giant lion-paw scallops (Nodipecten subnodosus) sampled from December to June ( $\mathrm{n}=5$, for each sampling). Unifactorial ANOVA followed by Tukey post-hoc analyses were applied to assert the differences between means; means sharing the same superscript are not significantly different $(P<0.05)$. The male gonad was only analyzed in June, and was compared to the female gonad sampled in June by a $t$-test, and significant differences are shown with an asterisk. 
Table 1. Lipid concentration (mg/g wet tissue \pm standard error) analyzed by TLC-FID in four tissues of giant lion-paw scallops (Nodipecten subnodosus) sampled from December to June. Unifactorial ANOVA followed by Tukey post-hoc analyses were applied to assert the differences between means; means not sharing the same superscript within the same row are significantly different $(P<0.05)$. The gonad in June was separated into female and male, and was compared by a $t$-test, and significant differences are shown with an asterisk.

\begin{tabular}{|c|c|c|c|c|c|c|}
\hline & & $\begin{array}{c}\text { Dec. } 99 \\
(n=5)\end{array}$ & $\begin{array}{c}\text { Feb. } 00 \\
(n=5)\end{array}$ & $\begin{array}{c}\text { Apr. } 00 \\
(n=5)\end{array}$ & $\begin{array}{c}\text { Jun. } 00 \\
(n=5)\end{array}$ & $\begin{array}{c}\text { Jun. } 00\left({ }^{\lambda}\right) \\
(n=5)\end{array}$ \\
\hline \multirow{5}{*}{$\begin{array}{l}\bar{T} \\
\text { تี }\end{array}$} & TG & $0.7 \pm 0.4 a$ & $11.5 \pm 5.3 \mathrm{ab}$ & $29.2 \pm 5.4 \mathrm{bc}$ & $51.6 \pm 7.6 \mathrm{c}$ & $0.7 \pm 0.3^{*}$ \\
\hline & FFA & $0.2 \pm 0.03 a$ & $1.1 \pm 0.13 c$ & $0.1 \pm 0.01 \mathrm{a}$ & $0.6 \pm 0.16 b$ & $0.4 \pm 0.1$ \\
\hline & ES & $0.4 \pm 0.2$ & $0.3 \pm 0.2$ & $0.7 \pm 0.5$ & $0.8 \pm 0.7$ & $0.02 \pm 0.01^{*}$ \\
\hline & FS & $2.0 \pm 0.3$ & $2.4 \pm 0.4$ & $2.1 \pm 0.3$ & $2.8 \pm 0.7$ & $4.2 \pm 0.8$ \\
\hline & PL & $4.7 \pm 0.4 a$ & $8.2 \pm 0.6 a$ & $6.9 \pm 0.5 a$ & $14.8 \pm 1.9 \mathrm{~b}$ & $12.3 \pm 0.5$ \\
\hline \multirow{5}{*}{ 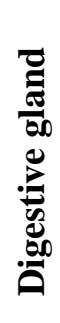 } & TG & $38.1 \pm 10.1 \mathrm{a}$ & $37.1 \pm 9.4 a$ & $252 \pm 24 b$ & $277 \pm 40 b$ & \\
\hline & FFA & $0.6 \pm 0.1$ & $0.5 \pm 0.3$ & $1.1 \pm 0.2$ & $1.7 \pm 0.8$ & \\
\hline & ES & $1.0 \pm 0.2$ & $1.1 \pm 0.4$ & $2.4 \pm 0.9$ & $2.9 \pm 1.1$ & \\
\hline & FS & $2.1 \pm 0.1$ & $2.2 \pm 0.2$ & $1.5 \pm 0.3$ & $1.9 \pm 0.5$ & \\
\hline & PL & $9.9 \pm 1.8$ & $14.4 \pm 1.3$ & $16.1 \pm 1.4$ & $18.2 \pm 3.4$ & \\
\hline \multirow{5}{*}{ 苋 } & TG & $0.11 \pm 0.03 a$ & $0.02 \pm 0.01 b$ & $0.07 \pm 0.01 \mathrm{ab}$ & $0.03 \pm 0.01 b$ & \\
\hline & FFA & $0.02 \pm 0.01$ & $0.03 \pm 0.01$ & $0.03 \pm 0.01$ & $0.05 \pm 0.01$ & \\
\hline & ES & $0.03 \pm 0.01$ & $0.01 \pm 0.01$ & $0.09 \pm 0.04$ & $0.06 \pm 0.03$ & \\
\hline & FS & $2.0 \pm 0.15$ & $2.0 \pm 0.18$ & $1.9 \pm 0.04$ & $1.7 \pm 0.18$ & \\
\hline & PL & $6.1 \pm 0.6$ & $9.0 \pm 1.6$ & $8.8 \pm 0.5$ & $7.0 \pm 0.9$ & \\
\hline \multirow{5}{*}{ 苋 } & TG & $0.01 \pm 0.01$ & $0.03 \pm 0.01$ & $0.05 \pm 0.02$ & $0.11 \pm 0.07$ & \\
\hline & FFA & $0.01 \pm 0.01$ & $0.02 \pm 0.01$ & $0.02 \pm 0.01$ & $0.02 \pm 0.01$ & \\
\hline & ES & $0.01 \pm 0.001$ & $0.01 \pm 0.001$ & $0.01 \pm 0.001$ & $0.01 \pm 0.001$ & \\
\hline & FS & $1.4 \pm 0.1$ & $1.6 \pm 0.2$ & $2.1 \pm 0.2$ & $1.9 \pm 0.2$ & \\
\hline & PL & $4.1 \pm 0.2 \mathrm{a}$ & $5.3 \pm 0.5 a b$ & $6.6 \pm 0.45 b$ & $6.5 \pm 0.63 b$ & \\
\hline
\end{tabular}

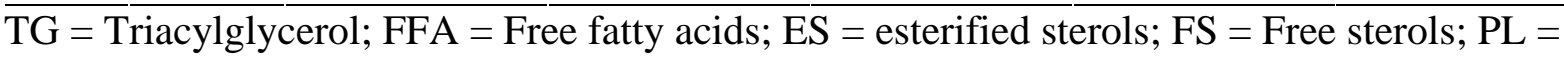
Total phospholipids 